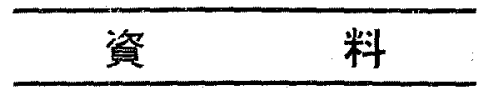

(昭和 38 年 5 月 27 日受理)

\title{
[被服科学研究委員会]
}

\author{
繊維の水分に対する性能につレて (1)
}

$\begin{array}{lllll}\text { 文化女子短期大学 } & \text { 小 } & \text { 川 } & \text { 安 } & \text { 朗 } \\ \text { 日本女子大学 } & \text { 三 } & \text { 平 } & \text { 和 } & \text { 雄 }\end{array}$

\section{I. 序文}

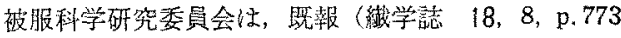
(1962)）の々抢り，昭和 37 年 7 月 6 日の第 173 回理事会 に括いて，瀻維学会の部門研究委員会の一つとして発足 L, 昭和 37 年 7 月 9 日に第 1 回委員会を開催して以来, これまで８回の会誐をもち，その都度，その概要を本

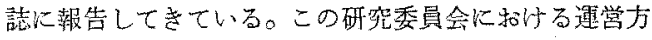

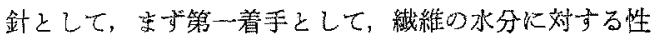
能を，被服村料としてて立場から㛟討することとし，研

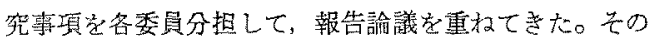
状沉は，つぎのようで女る。

筙 1 回委員会 委員会の運掌纪関方る基本方針の諭議， 決定

第 2 回委員会 透湿について一三平委員，酒半委員

第 3 回委員会 吸水速度について一平山涹員

第 4 回委員会 吸办機整について一大野委員

第 5 回委員会 脱水, 乾燥について一樋口委員

第6 回委員会 紻維と水分々の関係化ついての基濋理 論一牧島委員

第 7 回委員会 透湿一般飞ついて一三五委員

第 8 回委員会 以上各項の総合㛟討，今後の展開方針 についての協議など

以上の研究について，その内容の概要を，以後本誌に 報告して研究参考汇資する意味で，今後揭載をつづける 部画て蜜石。

\section{II. 透湿性に関する問題}

織維，标の水蒸気透過汇関する性筫を透湿性とよんで いるが，被服の着用性能を証価する重要な間題である。 Kaswell ${ }^{11}$ 注水蒸気伝達の問題として系統的に专の概要 を説明しているが，衛生学的炕見风九ばつぎのようにな る。人体が着心地の良し悪しを感ずるのは湿氮が皮嘚面
から蒸発する程度で定まり，この蒸発柱人体の熱的調節 として行なわれているから，被服がその蒸発をどこ年で

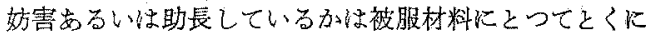
注意を执わなければならない。Rees 饮上れば不感知汗

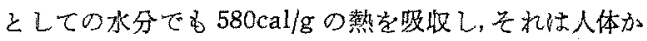
らの㪇消失量の $25 \%$ 炕当るといわれている。人体は休息

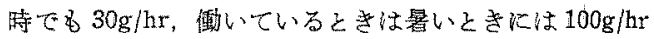

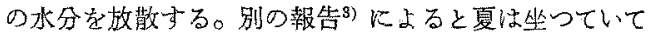
も感知でるる汗が $2 l$ 日，不感知汗が $1 l$ 日発生する といわれている。被服が着心地の上いためには湿氮を摭 散させることであり，Carlene $e^{4)}$ の定義の中にもまげら れている。(Carlene ほ着心地の 4 要因として，水蒸気 の透湿性, 瀻維の昅収量と水分保持量, 繊維に上る水の 吸収熱，瀻維の乾燥を党げている。

\section{（1）挔散による水蒸氮透過性の一般式}

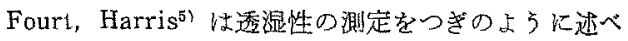
ている。布の透湿性は理想的な静止した空気の中を水蒸 気が通過するときの抵抗と比較するのが妥当で，理想的 な静止架気の $1 \mathrm{~cm}$ の抵抗を単位 (cm-air) としてとる ことができる。翼つた布を比軟するたか心は単位厚さ当 りの抵抗の上5な相対的抵抗 (xair) を計算するのが便 利で台る。出る層を通つて水蒸気が定常的に拻散するの は電流の場合と同じ取扱いができてポテンシャル（こ

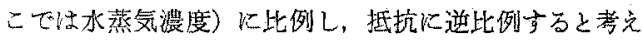
ら机る。

そこて

$R:$ その系の全抵抗（静止空気火相当する $\mathrm{cm}$ で与 完られる

$Q:$ 通過与る水蒸気の量 $(\mathrm{g})$

$D:$ 搪散係数 $\left(\mathrm{cm}^{2} / \mathrm{sec}\right)$

$\Delta C:$ 水蒸気濃度の差 $\left(\mathrm{g} / \mathrm{cm}^{3}\right)$

$A$ : 実際の水蒸気通路の面積 $\left(\mathrm{cm}^{2}\right)$

$t:$ 時間 $(\mathrm{sec})$

で出らかすと， 


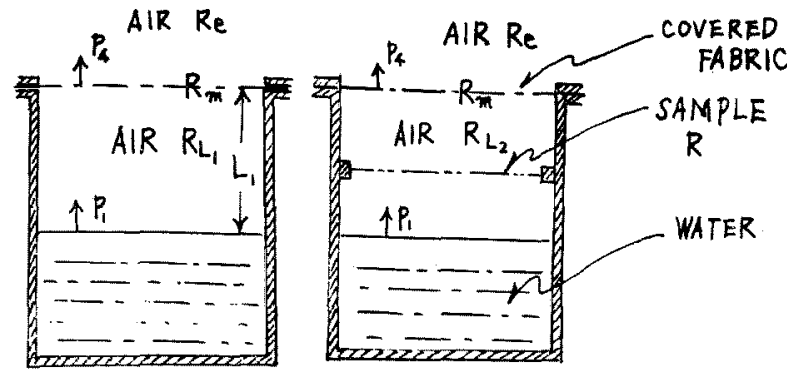

第 1 图

$$
R=\frac{1}{Q} \cdot D(\mathcal{A}) \cdot A \cdot t
$$

で示される。

(1)式に执いて $T$ 学絶坟温度, $p$ 水蒸気压 $(\mathrm{mmHg})$ とすると Dは

$$
D=0,220\left(\frac{T}{273}\right)^{1.75} \cdot 760
$$

となり，温度が $0 \sim 50^{\circ} \mathrm{C}$ の閒では実用的には

$$
D=0.220+0.00147 m
$$

ここで $m$ は温度 $\left({ }^{\circ} \mathrm{C}\right)$ をあらわす。

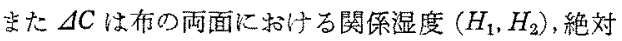
温度 $\left(T_{1}, T_{2}\right)$, 蒸気压 $\left(p_{1}, p_{2}\right)$ 加与次式に上つて得られ ๖。

$$
\Delta C=\frac{18}{22400} \cdot \frac{273}{760} \cdot\left(\frac{p_{1} H_{1}}{T_{1}}-\frac{p_{2} H_{2}}{T_{2}}\right)
$$

ある温度に詨しては

$$
\Delta C=2.89 \times 10^{-4} \times\left(p_{1}-p_{2}\right) / T
$$

でる。

以上の内容をるつて空気中の単位面積当りの水蒸気伝

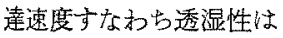

$$
\frac{Q}{A T}=\frac{\Delta C \cdot D}{R}
$$

てもらるされる。

以上は完全な系の全抵抗，全透湿性をあらわしている が，布本来の抵抗はその上に布餍が付加したときの全抵 抗との差加ら決定される。この場合布を含至 2 系の全抵

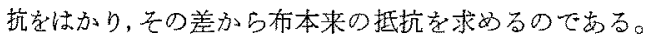

\section{（2）測定法}

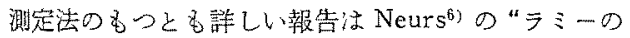
蒸気渗透性測定の研究”の中文献の一覧表がある。こ こではそのずててを揭げることは不可能で虬る。

\section{a，助取コップ浩}

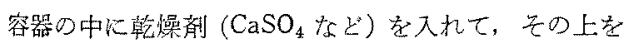

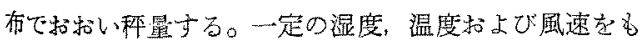
外界に放置して，外界の水分が布老透して乾燥剂以吸

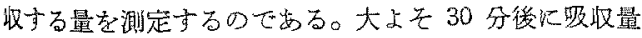

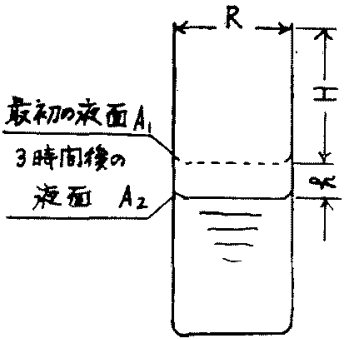

筑 2 图
は一定となるが，2時間きさはとれ以上放監するとよい。 同椂な方法性酼酸と外気々の間で有の透湿性定知るこ とによつても陚市れていら7。

b. 蒸発法 (1)

容器の中に水を入れてその上を試布て和扮引。容器中 の水加外界人苴発することによつて水の量が減少吉るか ら，その減韩から布の透湿量を知るのであるそのとき 有と水面との距離を Fourt, Harris ${ }^{6)}$ は $1 \mathrm{~cm}$ と定めて いるが，ASTM ヤ TAPPI で $2.5 \mathrm{~cm}$ と定めている。 西万え外界は一定湿度, 温度执上び一定風速に保ち, 水量の減少速度を一定時間々隔で剆定するのである。

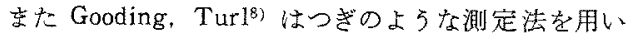
tio

第1図のよ5なシリコン樹脂を $300^{\circ} \mathrm{F}, 10$ 分焼付加工 した金属容器を用い，その中に水を入れる。一つの装嘿

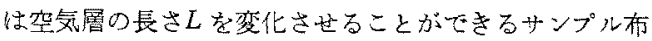
を入れない装埴とし，他の一つは穴あき金属板つ上《サ ンプル布を扣いたものを中に聥入する。装置忙 $20 \mathrm{ft} / \mathrm{min}$ の風速をるた $65+2 \% ， 70+2^{\circ} \mathrm{F}$ の外界に放犆されて 2 時間後々 16 17 時間後の水の減量を湘定する。

因比和化

$p_{1}, p_{1}$ : 水面䋇よび外界 (const) の水蒸気生

$R_{I_{1}}:$ 容器内の空氮賞の抵坑

$R_{m}:$ 上蔽布の抵抗

$R_{e}:$ 外気屬の抵抗

$R_{l_{2}}$ : 試布加方るときの容器内つ空気層の抵㧧 とすると

容器から蒸菆が失なわれる速度は容器内外の空気層と 布の抵抗の台計の抵机に支配されるから，つぎ拡散式 が成立つ。

$$
\left.\begin{array}{l}
U_{1} \propto\left(p_{1}-p_{1}\right) /\left(R_{I_{1}}+R_{m}+R_{e}\right) \\
U_{2} \propto\left(p_{1}-p_{4}\right) /\left(R_{I_{2}}+R_{m}+R+R_{e}\right)
\end{array}\right\}
$$

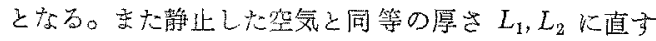




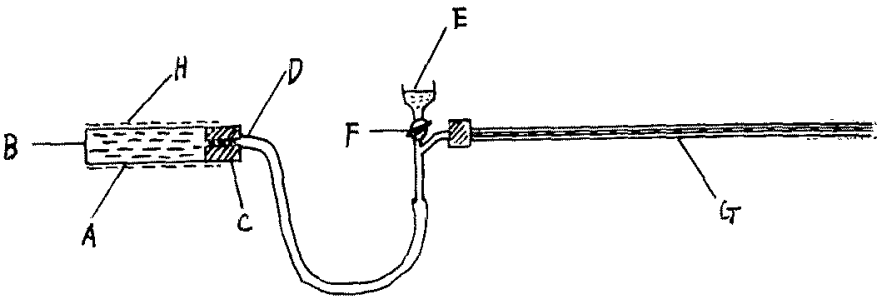

A : a cylindrical porous pot. 10 inches $10 \mathrm{xg}$ axd 2.8 inches diameter

$B$ : Hat end, made impermeable to water ve pour by a thick layer of piceix Wax.

$C$ : \& rubber bung

$D$ : the inlet tube.

$E$ : the reservoir.

$F$ : the Stop top.

or: the gradusted capillary tabe.

$H$ : the Tebric.

之

$$
R=L_{1}-L_{2}
$$

この類型として，あらかじめ定められた抵抗 $R_{\mathrm{S}}$ をる つ布と，末知の抵抗 $R_{x}$ をる口布を此較するとをは，

$$
U_{1} / U_{2}=\left(R_{L}+R_{x}+R_{e}\right) /\left(R_{L}+R_{s}+R_{e}\right)
$$

がら $R_{x}$ を求めることができる。

c. 蒸発法 (2)

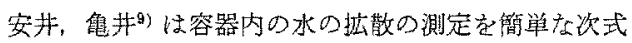
で示している。すなわb

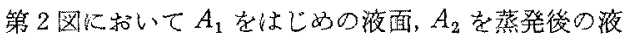
面とするとさ蒸䇥後の液面の減少高さ $h$ は，水䔲気拡散 の式少

$$
h=\frac{D \cdot \Delta C}{d \rho} t
$$

ですらかされる。ここにdは皮面上部の分子搪散が行な われる空氛屬の愿さて， $d=H+h / 2$ てあらわされる。 仿溶液の密度でる。

しかし近似的には容器つ蒸発面積が小さく, 容器の直 佳 $R$ と水学での高さ $H$ との比 $H / R$ が大ならば,

$$
h=\frac{D \cdot \Delta C}{H \cdot \rho} t
$$

が成立する。

そこでAが小なる場合は毛布など氷蒸氛透過のモデ ルになりらるとして（毛布の $H / R=3$ ）蒸気拉散の式が

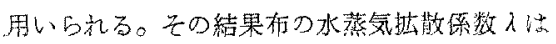

$$
\lambda=d \cdot \rho \cdot h / \Delta C \cdot t
$$

ただし $d:$ 試布つ厚さ， $\Delta C$ : 水蒸惑密度つ差， $h:$ 液 面て減少高さで岁る。ここで圾試有の雨面に $A C$ をつく ることにすると，外界の温度を約 $70^{\circ} \mathrm{C}$ の恒温就燥器に 入れるのがよ。

d. 蒸発法 (3)

Peirce, Rees 拈よび Ogden ${ }^{10)}$ の方法である。第 3
图に示市上らに，水を湍たした多孔 性の容器を，水蒸気以通すが水を遥 さないセルロースアセテートのシー トで扣拓い，その上を試布で包えで， 容器の中の水の減少を測定し, 水蒸 気透渦に対す方布地の抵抗を求める のである。

いま外界の空気の湿度を $E$, 測定 された湿気伝達速度孝 $F_{b}$ ，多孔性 ボットとセルロースアセテートのシ

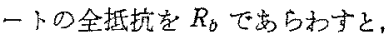

$$
R_{b}=\frac{100-E}{F_{b}}
$$

となる。

签器の内側の湿度は $100 \%$ でる が、このとき容器に封入されている空気の湿度を50〜 $90 \%$ に変化してb， $F_{b}$ 乙 $(100-E)$ との間には直線的 関係が保たれる。

そこで，今度は容器を布にて包み，布を通しな蒸発量 の测定を行な5。そのとき全抵抗を $R_{m}$ ，布の抵抗を $r$ 、はかられた水苲気伝達速度を $F_{m}$ とすると，

$$
R_{m}=R_{b}+r=\frac{100-E}{F_{m}}
$$

が成立する。

(9)(10)加占結局

$$
\begin{aligned}
r= & (100-E)\left(\frac{1}{F_{m}}-\frac{1}{F_{b}}\right) \\
& \text { (R. H./gram/meter } / \text { second) }
\end{aligned}
$$

が莎た觉られる。

な祸 $R_{b}$ はセルロースアセテートのシートのとき蚛， $12.2 \times 10^{2}$ を示した。京た抵抗は蒸気在 $/\left(\mathrm{g} / \mathrm{m}^{2} / \mathrm{sec}\right)$ が基

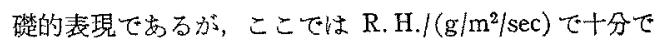
岁る。

e. 午の他の方法

(i) 竹中 ${ }^{11}$ は第 4 図に示す上5に，金属円筒中に一

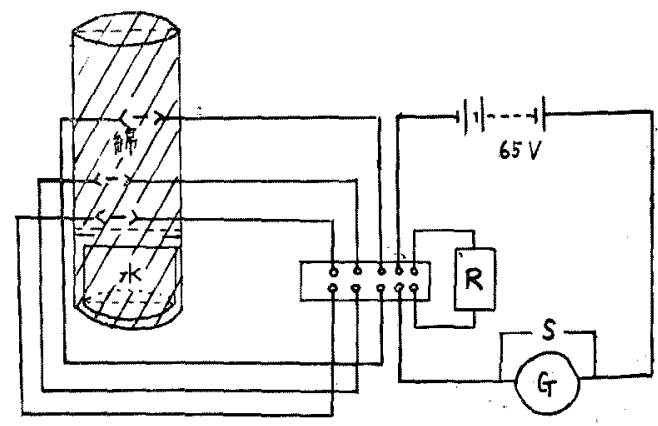

第 4 図 


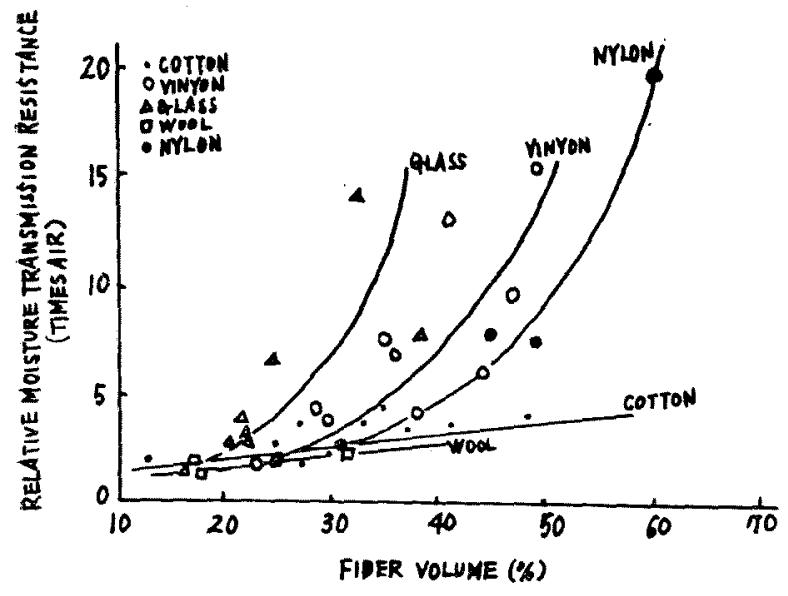

第 5 図

定重量のわたを充垻し，一方の底面を高温度に保もなが ら，わたの中に水蒸気が浸透して行く状㣞を，わたの中 に挿入した濾紙の電受抵抗の变化を測定することにより 㒛パた。

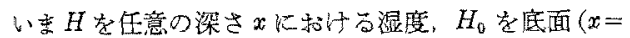

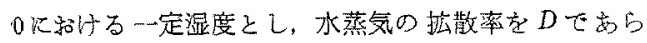
わすと，熱の伝導の考皇を導入して

$$
H=\frac{2 H_{0}}{\sqrt{\pi}} \int_{2 D \sqrt{t}}^{\infty} e^{-\beta^{2} d \beta}
$$

る得る。これから口を求めることができる。

(ii) 井上 1") $^{2}$ 一定湿度に保つた保温箱の中に 2 枚の

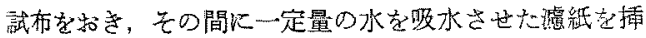
入して濾紙の水分が蒸発し終加るまでの水分の減䁷速度 を5分每に科量して調べれば布の透湿性が湘定できると している。試験前に滤紙炕含有させた水分量を $A, 5 \times n$ 分経過每の澺紙火残存する水分量を $B_{n}, B_{n}-B_{n-1}=C_{n}$ とするとき，透湿度乩よび蒸発度は

$$
\begin{aligned}
& \text { 透湿腐 }=\left(1-B_{n}-A^{-}\right) \times 100 \% \\
& \text { 蒸発度 }=\frac{C_{n}}{A} \times 100 \%
\end{aligned}
$$

であらわされる。

(iii) 多田 ${ }^{13}$ ) は絶対乾噪した板状つ綿塊試料堂桓温佰 湿室条件下以放琵し20時間每以吸湿量学測定して次式か ら湿気搪散保数を求めている。すなわ湿気拉散数 $\left(\mathrm{cm}^{2}\right)$

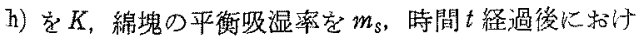
砐湿率を的七し，綿塊の厚さをdてあらわすと

$$
\left.\begin{array}{c}
K t / d^{2}<0.06 \text { では } m_{t} / m_{s}=\frac{4}{\sqrt{\pi}} \sqrt{\frac{K t}{d^{2}}}<0.555 \\
K t / d^{2}>0.06 \text { では } m_{t} / m_{s}=1-\frac{8}{\pi^{2}} \quad>0.552
\end{array}\right)
$$

（3）布の性䈏と抵抗との関保

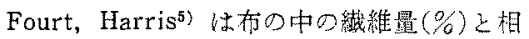
对的湿気伝達抵抗（空気㤟厚さの倍数）の関係 を各種つ蟣物について比較している。その結果 は第 5 図以示すようで台。

ガラス瀻維つ有とビニヨン織維の布は急激に

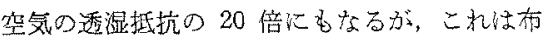
の中心湿気の通路となるえ5な空間加するた めである。綿布はようゃく4倍，羊毛も(こ北

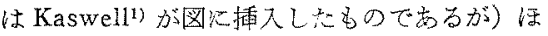

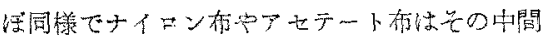
に位与る。乙して各布共䋐維含有率が30 40\%

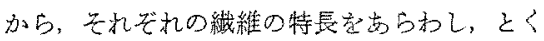
に水になじすない繊維の抵抗增加がシャープに あられる。30\%以下の䋊維合有率ではこの 上5な差奴られない。

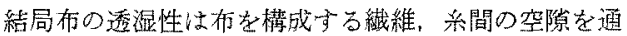

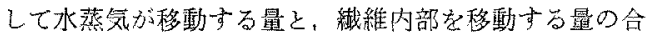
計によつて定まつてくるのである。てこで法上通のよの

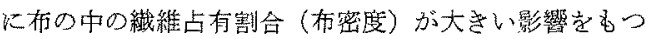
ている。

各種の布の抵抗定示すと第 1 〜表のようになる。

（4）緎維内部老通過する水蒸気の抵抗 ${ }^{14}$

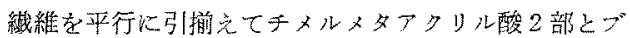
チルメタアタリル酸 8 部による混合樹脂中に封入し, 減

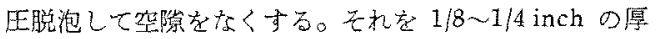

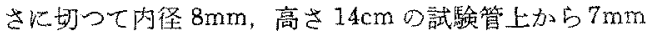
昰で飽和 $\mathrm{NH}_{4} \mathrm{H}_{2} \mathrm{PO}_{4}$ 溶液を入れ，管の入口に試料を中 一村 ᄂ $\mathrm{Mg}\left(\mathrm{NO}_{3}\right)_{2} \cdot 6 \mathrm{H}_{2} \mathrm{O}$ 溶液のデシタータの中K入

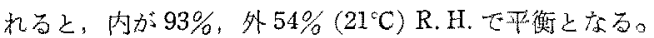

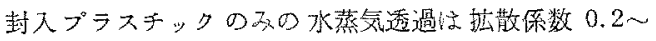

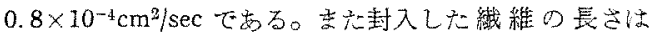
透湿量と直線関係儿るることを確認して

$$
D_{F}=\begin{aligned}
& Q \cdot L \cdot M_{F} \\
& F \cdot t \cdot(\Delta C)
\end{aligned}
$$

力口戝維の摭散係数を测定した。ここに $M_{F}$ : 試料中の 瀻維含有密度, $A=F / M_{F}, F$ : 試紏 $1 \mathrm{~cm}$ 当り口䋐維量 である。

織維は一般任低湿度ては透湿性が少ないが，通常各種

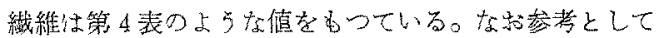

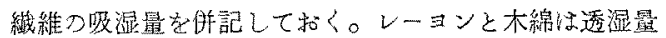
と吸湿量の閔係が反対になつていることは注目される。

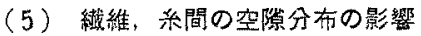

はじめK Peirce ${ }^{10)}$ らは布の透湿性の加法性てついて 定性的実駰を試み，1枚の布の透湿抵抗と同じ打の2 枚,

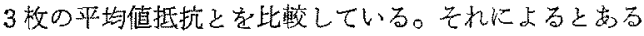


第 1 表

\begin{tabular}{|c|c|c|c|c|c|c|}
\hline \multirow[b]{2}{*}{ Fabric } & \multirow[b]{2}{*}{$\begin{array}{c}\text { Fiber vol } \\
(\%)\end{array}$} & \multirow[b]{2}{*}{$\begin{array}{l}\text { Weight } \\
\left(o z / y^{2}\right)\end{array}$} & \multirow[b]{2}{*}{$\begin{array}{l}\text { Thickness } \\
\text { (in) }\end{array}$} & \multirow{2}{*}{$\begin{array}{l}\text { Air Perm- } \\
\text { eability } \\
\left(\mathrm{ft}^{3} / \mathrm{ft}^{2} / \mathrm{min}\right)\end{array}$} & \multicolumn{2}{|c|}{$\mathbf{R}$} \\
\hline & & & & & $\mathrm{cm}$ air & Xair \\
\hline $\begin{array}{l}\text { (Corton) } \\
\text { knit } \\
\text { undershirt }\end{array}$ & 13 & 4.2 & 0.028 & 223 & $\left(\begin{array}{c}0.12 \\
(0.07)\end{array}\right.$ & $\left\{\begin{array}{c}1.7 \\
(1.0)\end{array}\right.$ \\
\hline bedford cord & 27 & 13.6 & 0.043 & 6 & $\left(\begin{array}{c}0.37 \\
(0.41)\end{array}\right.$ & $\left\{\begin{array}{c}3.4 \\
(3.8)\end{array}\right.$ \\
\hline sateen & 34 & 9.7 & 0.025 & 6 & $\left\{\begin{array}{l}0.165 \\
(0.185)\end{array}\right.$ & $\left\{\begin{array}{l}2.62 \\
(2.94)\end{array}\right.$ \\
\hline $\begin{array}{l}\text { uniform twill } \\
\text { (Vinyon) }\end{array}$ & 35 & 8.2 & 0.022 & 12 & $\left\{\begin{array}{l}0.23 \\
\cdots \cdots\end{array}\right.$ & $\left\{\begin{array}{l}4.2 \\
\cdots \cdots\end{array}\right.$ \\
\hline knit & 23 & 4.8 & 0.021 & 256 & $\left\{\begin{array}{c}0.090 \\
(0.070)\end{array}\right.$ & $\left\{\begin{array}{l}1.7 \\
(1.3)\end{array}\right.$ \\
\hline sail cloth & 35 & 2.55 & 0.025 & 1 & $\left\{\begin{array}{c}0.464 \\
(0.473)\end{array}\right.$ & \\
\hline filter & 38 & 14.8 & 0.033 & 9 & $\left\{\begin{array}{c}0.34 \\
(0.38)\end{array}\right.$ & $\left\{\begin{array}{c}4.0 \\
(4.5)\end{array}\right.$ \\
\hline (Glass) & & & & & & $(2.62$ \\
\hline $\operatorname{css}-20$ & 20.4 & 24.3 & 0.057 & 8.6 & $\left\{\begin{array}{l}0.38 \\
(0.365)\end{array}\right.$ & $\left\{\begin{array}{c}2.62 \\
(2.52) \\
3.54\end{array}\right.$ \\
\hline WB-0046 & 21.6 & $\cdots$ & 0.058 & $\cdots$ & $\left\{\begin{array}{l}0.521 \\
(0.438)\end{array}\right.$ & $\left\{\begin{array}{c}3.54 \\
(2.98)\end{array}\right.$ \\
\hline $\begin{array}{l}\text { no designation } \\
\text { (Wool) }\end{array}$ & 38.8 & 9.6 & 0.013 & $\cdots$ & $\left\{\begin{array}{l}0.33 \\
(0.31)\end{array}\right.$ & $\left\{\begin{array}{c}7.0 \\
(7.5)\end{array}\right.$ \\
\hline serge & 25 & 10.4 & 0.038 & 12 & $\left\{\begin{array}{c}0.18 \\
(0.26)\end{array}\right.$ & $\left\{\begin{array}{c}1.9 \\
(2.7)\end{array}\right.$ \\
\hline $\begin{array}{l}\text { serge }(45 \% \text { vis- } \\
\text { case } 55 \% \text { wool })\end{array}$ & 31 & 11.5 & 0.033 & 10 & $\left\{\begin{array}{c}0.20 \\
(0.18)\end{array}\right.$ & $\left\{\begin{array}{c}2.4 \\
(2,1)\end{array}\right.$ \\
\hline felt & 17 & 31.3 & 0.184 & 16 & $\left\{\begin{array}{c}0.80 \\
(1.10)\end{array}\right.$ & $\{(2,4)$ \\
\hline (Nylon) & & & & & 0.16 & 2.5 \\
\hline knit & 31 & 6.5 & 0.025 & 108 & $(0.15)$ & $(2.3)$ \\
\hline twill & 49 & 4.6 & 0.001 & 20 & $\left\{\begin{array}{c}0.20 \\
(0.18)\end{array}\right.$ & $\left\{\begin{array}{c}7.1 \\
(6.4)\end{array}\right.$ \\
\hline mountain tent & 60 & 3.2 & 0.006 & 2 & $\left\{\begin{array}{c}0.32 \\
(0.33)\end{array}\right.$ & $\left\{\begin{array}{c}20.0 \\
(20.6)\end{array}\right.$ \\
\hline
\end{tabular}

Method : absorption \& (evaporation) 交献(5)より主なる例索抽出した。

$$
\text { 第 } 2 \text { 表 }
$$

\begin{tabular}{|c|c|c|c|c|}
\hline Sample & $\begin{array}{c}W t \\
\left(o z / y^{2}\right)\end{array}$ & $\mid \begin{array}{c}\text { Thickness } \\
(\text { in } / 1000)\end{array}$ & $\begin{array}{c}\text { Resistance } \\
\text { (R. H./gm, } \mathrm{m}^{-2} \text {. } \\
\mathrm{sec}^{-1} \text { ) }\end{array}$ & $\begin{array}{l}\text { Ratio Equiv. } \\
\text { Air thickness } \\
\text { Fabr. Thik. }\end{array}$ \\
\hline British army wool shirting & 7.0 & 69 & $5.5 \times 10^{2}$ & 1.6 \\
\hline cashmere fabric & 15.0 & 225 & $16.3 \times 10^{2}$ & 1.5 \\
\hline R. A. F. melion & 19.5 & 135 & $12.1 \times 10^{2}$ & 1.8 \\
\hline U.S. Officer's overcoating & 21.3 & 142 & $11.5 \times 10^{2}$ & 1.6 \\
\hline heavy wool overcoating & 25.5 & 375 & $22.9 \times 10^{2}$ & 1.3 \\
\hline gabardine & 3,2 & 18 & $1.3 \times 10^{2}$ & 1.5 \\
\hline close weave cotton fabric & 7.1 & 34 & $3.6 \times 10^{2}$ & 2.1 \\
\hline " & 9.3 & 40 & $4.7 \times 10^{2}$ & 2.4 \\
\hline " $\quad$ " & 4.3 & 21 & $2.8 \times 10^{2}$ & 2.6 \\
\hline cotton tent duck, undyed & 19.6 & 75 & $8.0 \times 10^{2}$ & 2.1 \\
\hline nylon parachute fabric & 1.6 & 7 & $3.4 \times 10^{2}$ & 9.7 \\
\hline silk parachute fabric & 1.6 & 6 & $1,2 \times 10^{2}$ & 3.8 \\
\hline P.V.C.coated cotton fabric & 8.3 & 20 & $143.5 \times 10^{2}$ & 14.4 \\
\hline
\end{tabular}

交献 (10)上り主なる例离抽出した。

の值を有し, 平均 1 枚 当り $3.7 \times 10^{2}$ の抵抗 でをることを確認し た。きた氷蒸気透過坻 抗と极の通気性との間 ch British Array Wool Shirting $\not * 0.02$ の通気性能をもつて, $5.5 \times 10^{2}$ の透湿抵抗它

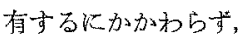
Close Weave Cotton Fabric No. 2 は 2.7 の通気泩老有しながら 姡愺同じ $5.2 \times 10^{2}$ の 潘湿抵抗を有古をこと を示している。をた同 質の鐵維でつくられた キャンパスについて 通気性が 16.7>7.7> 2.2 と異なる 3 種の布: の透湿抵抗が，その順 に $12.3 \times 10^{2}, 9.3 \times 10^{2}$, $11.4 \times 10.2^{2}$ の透湿抵 抗を示し，布構造纪よ る差学強調している。

つぎに第 6 罒は布の 愿さに対する透湿抵抗 の閶係考示可。図炕よ れば理諭的に水蒸舞の 抬散係数から計算した 空気層の線よりいずれ の繊維の布当抵抗が大 きく，とくに Doped

Fabric が为忛はなれ ていることがわかる。 しかし多くの布の热抗 と厚さとの間には明瞭 尔関係が台ることがわ。 かる。要第7圈保希

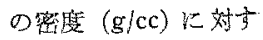
る猚の透湿抵抗に等し い些気抵抗をむつ空気

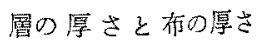
の比との関係を示す。 有に一、七，1枚の抵抗が $3.6 \times 10^{2}$, (R.H./g, $\mathrm{m}^{-2}$, $\left.\sec ^{-1}\right)$ てるる柯は，2枚さ $7.8 \times 10^{2}, 3$ 枚で $10.6 \times 10^{2}$ ナイロンの一点発除いて, Peirce bは次の式を見出し た。术放占 
第 3 表

\begin{tabular}{|c|c|c|c|}
\hline 織 & $\begin{array}{l}\text { 抵 抗 } R \\
(\mathrm{~mm} \text { air })\end{array}$ & $(\mathrm{mm})$ & 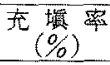 \\
\hline 平 & 1.3 & 0.31 & 32 \\
\hline 綾 & 1.5 & 0,41 & 24 \\
\hline 平 & 1.2 & 0.84 & 14 \\
\hline$n$ クランネル & 1.9 & 0.99 & 10 \\
\hline 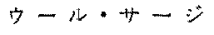 & 2.9 & 1.05 & 27 \\
\hline シュク・タレ-プ & 0.8 & 0.15 & 28 \\
\hline ナイロン平緎 & 1.1 & 0.17 & 41 \\
\hline$\neg \simeq ル r$ & 2.8 & 1.9 & 11 \\
\hline
\end{tabular}

文苚 (8)上り主なる例を抽出した。

第 4 表

\begin{tabular}{|c|c|c|c|c|c|}
\hline 緎 & & & 維 & $\begin{array}{c}D_{F} \\
\left(\mathrm{~cm}^{2} / \mathrm{sec}\right)\end{array}$ & 吸 $\begin{array}{c}\text { 湿 } \\
(\%)\end{array}$ \\
\hline 木 & & & 綿 & $114 \times 10^{-4}$ & 7 \\
\hline 2 & - & $\exists$ & $y$ & $48 \sim 61 \times 10^{-4}$ & 11 \\
\hline 羊 & & & 毛 & $17 \sim 45 \times 10^{-4}$ & 13 \\
\hline ナ & 1 & 口 & ン & $6 \sim 9 \times 10^{-4}$ & 4.5 \\
\hline ş & $\Rightarrow$ & $=$ & ע & $4 \sim 8 \times 10^{-4}$ & 0.4 \\
\hline
\end{tabular}

小亲 $V$ : 布の全比容積 $(c c / g)$

$v_{f}:$ 瀻維の容積 $(\mathrm{cc} / \mathrm{g})$

$r_{a}:$ 空気 $1 \mathrm{~cm}^{9}$ の抵抗

$r_{f}:$ 㖪維 $1 \mathrm{~cm}^{3}$ の抵抗

$R:$ 厚さ $d \mathrm{~cm}$ の布の抵抗

とすると布の1cc中の緎維の容積は， $v_{f} / V$ となり，布抵 抗に等しい抵抗をるつ空受層の厚点は $D=R / r_{a}$ であら

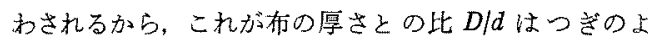
らになる。

$$
\begin{aligned}
\frac{D}{d} & =R / d r_{a} \\
\text { よつて } \quad \frac{R}{d} & =r_{a}\left(1+\frac{v_{f}}{V}\right)+\frac{r_{f} \cdot v_{f}}{V} \\
& =r_{a}+\frac{1}{V}\left(r_{f}-r_{a}\right) v_{f} \\
& =1+\frac{1}{V}\left(\frac{r_{f}}{r_{a}}-1\right) \cdot v_{f}
\end{aligned}
$$

であらすされることになる。

(6) モデによる空隙分布の影響8

Whelan, Mac Hattie, Gooding, Turl 5は, 金属板

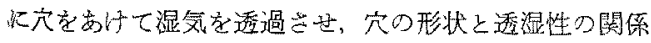
安つぎのよに説归した。

実験は金属板の直経 $D$, 金属板の節さ $T$, 穴口数 $N$, 穴の直径 $d$ を種々に変化させ心 72 種の試料金属板に

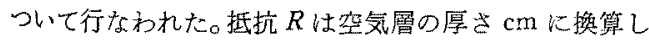
てあらわされた。得られた結果はつぎのようでかる。

(i) $d, N$ を一定としたとき，

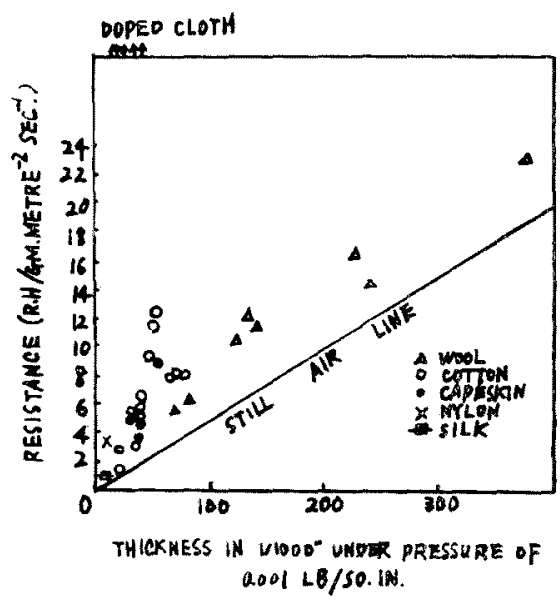

第 6 図

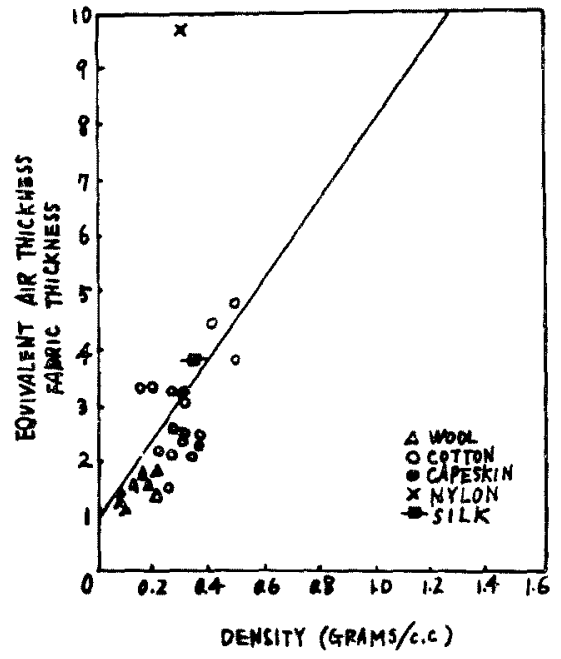

第 7 图

$$
R=\frac{D^{2}}{N d^{2}} \cdot T+b_{1}
$$

寸なわわ金属板の穴の直径と数を一定としたと音抵抗

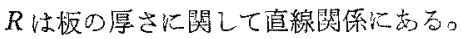

(ii) $T ， d$ を一定としたとき

$$
R=\frac{A_{2}}{N}+\frac{B_{2}}{V N}
$$

すなわb金属板の厚さ怙よび穴の直径を一定としたと き，抵抗は穴の逆数に関係をるつ。

(iii) $T, N$ 一定としたとき，Rとd， $d^{2}, 1 / d ， 1 / d^{2}$ との閵係杜いー゙れも曲線的関保をしつ。

(iv) $N d^{2}, T$ 右一定としたと童，

各金属板総面積に対して $N d^{2}=0.1 ， 1 ， 5 ， 10 ４ 0 \%$ 
のとき， $T=0.0508 \mathrm{~cm}, N d^{2} / D^{2}=0.050$ とすると，

$$
R=a_{3} d+b_{3}
$$

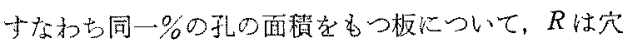

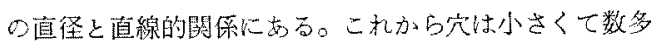
いほうが，大き敒穴で数少い場合よりRが抵いことが 方方至。

以上を総合孛と，

$$
R=\frac{T}{\beta}+K d\left(\frac{1}{\beta}-\frac{1}{V \beta}\right)
$$

行られる。ここに $\beta=N d^{2} / D^{2}$ て穴の然隙面積と板の 面㱴との比でる。K注（iv)のデータから約0.71の值 ๖る。

なお同氏らは，金属板の他に布についても実験を拡張 てている。その結果の主なるものはつぎのよ5である。 布の透湿抵抵は柯の愿さと関係があるが，同時に愿さ 以外に布表面の幾何学的形状にも関保がある。しかし金

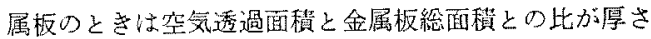
と深い関保を更つたが，布の場合はその穴がまがりく补 つて存在していると考玉てよい。5すい布は去のながり くねつた布の莓造がとくに重要でる。同じ組織で同一 目方ならぱ，5すい布は抵抗が大て古るが，布密度が20 $29 \%$ 籍国では $R=2.25 T+0.55$ が成立つ。しかし それ以外では厚さにばかり等㗽子るとは限らないが，通 路の長さは瀻維の重量(\%)の增加之同様に厚さに上つて

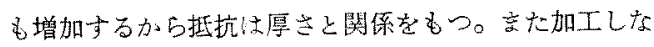
い布と加工した布ては同一材質の繊維，同一重量の二つ の杨が一見して厚さが異なる上らに見えても，ほとんど 同じ抵抗をるつことはありることて，空隙分布が大で 抵抗小なる布でニーチングによつて抵抗を增すこと 依可能でる。等々。

結局 Kaswel11 は透湿性についてつぎのよ5に結諭 している。

湿気の翰送の状態は布の両側に存在する湿気の差によ つて生じ，水蒸気は二つのメカニズムを通して移行寸
る。それは有の間隙を通しての移行と織維自身を通して の移行である。

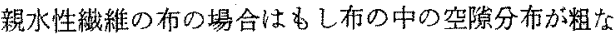
らば布の間隙を通つて湿気は移行し，布が密ならば䄉維 の中学移行する。両者の移行量が同じなら着心地忹と んど同じでする。しかし軣水性緀維の場合は布が粗なら

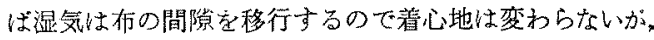
析が密ならば湿気の桩散の欠陷のゆ光に不快となるのて むる。

女 献

1) Kaswell ; Textile Fibers Yarns and Fabrics. Reinhold Publishing corporation, N.Y. (1953)

2) Rees, W.H ; J.Text. Inst., 37, p.132 (1946)

3) 小川; 被服㯕諭, 国土社（昭和 25)

4) Carlene, P. W ; I. C. I., DLR 20, 20, 1 (1945)

5) Fourt L. Harris, M ; Text. Res.J., 17, 256(1947),

6) Neurs ; J. Text. Inst., 50, 8, T.269 (1959)

7) 步野; 緎工学誌, 3, 4 (1937)

8) Whelan, MacHattie \& Goodings ; Text. Res. J.r 25, 197 (1955)

9) 安井，暒井；䋐維消科学誌，3，3 (1962)

10) Peirce Rees \& Ogden; J. Text. Inst., 36, T 169. (1945)

11）竹中；家政学雑誌，8，1 (1957)

12) 莐上; " 13,1 (1962)

13) 多田; " $7,3,7,4$ (1956) 11, 3(1960)

14) Fourt, Craig \& Rutherford; Text. Res.J., 27, 362 (1957)

その他の関連むる文献

15) 古矢; 䋡学誌, 9, 2, 9, 10, 9, 12 (1953)

16) 小田; 同上, 13，1，13，2（1957）

17) 石川；同上，13，4(1957)

18）西村，吉川1 ; 高知大学術研究報告, 3 4 (1954 1955)

19) Nordon, Mackay \& Donnes; Text. Res. J., 30, 761 (1960)

20) Mathieson ; J. Text. Inst., 52, 11, T, 477, T. 512 (1961)

(昭和 38 年 5 月 22 日受理)

\section{[紙パルプ研究委員会]}

叮解状態と紙の強度的性質との関係

$$
\text { 茎式会社巴川製紙所武袥一郎・八十鼠治雄 }
$$

\section{I. 緒商}

近年，紙の用途が次第に掘大されるにつれて，紙の諸
性質，特に強度的性質に対する要求が過酷になつてきて いる。紙の強度を支配する最大の因子はなんといつても 原料パルプの特性,すなわちパルプの化学的成分, 形態学 